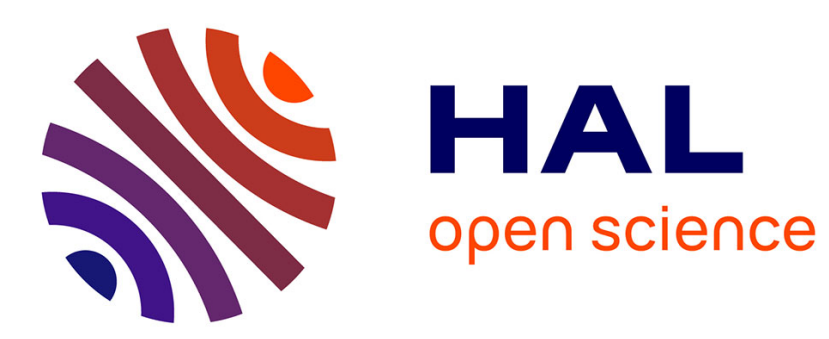

\title{
Hybrid perovskites for photovoltaics and optoelectronics
}

Antonio Tejeda, Wallace C H Choy, Emmanuelle Deleporte, Michael Grätzel

\section{To cite this version:}

Antonio Tejeda, Wallace C H Choy, Emmanuelle Deleporte, Michael Grätzel. Hybrid perovskites for photovoltaics and optoelectronics. Journal of Physics D: Applied Physics, 2020, 53 (7), pp.070201. 10.1088/1361-6463/ab59b2 . hal-03065282

\section{HAL Id: hal-03065282 \\ https://hal.science/hal-03065282}

Submitted on 14 Oct 2021

HAL is a multi-disciplinary open access archive for the deposit and dissemination of scientific research documents, whether they are published or not. The documents may come from teaching and research institutions in France or abroad, or from public or private research centers.
L'archive ouverte pluridisciplinaire HAL, est destinée au dépôt et à la diffusion de documents scientifiques de niveau recherche, publiés ou non, émanant des établissements d'enseignement et de recherche français ou étrangers, des laboratoires publics ou privés. 


\title{
Hybrid perovskites for photovoltaics and optoelectronics
}

\author{
Guest Editors \\ Antonio Tejeda ${ }^{1}$ Université Paris-Sud, Orsay, France \\ E-mail: antonio.tejeda@u-psud.fr \\ Wallace C H Choy \\ University of Hong Kong, People's Republic of China \\ E-mail: chchoy@eee.hku.hk \\ Emmanuelle Deleporte \\ ENS ENS Paris Saclay, Orsay, France \\ E-mail: emmanuelle. deleporte@ens-paris-saclay.fr
}

Michael Grätzel Ecole Polytechnique, Lausanne, Switzerland

E-mail: michael.graetzel@epfl.ch

Hybrid perovskites were traditionally studied for optoelectronic devices with significant success due to possibility of tuning different emission wavelengths with them. The interest in them exploded when they were used as the absorber material in a solar cell by Kojima et $a l$ [1] and their promising properties in the domain were made explicit. Since then, hybrid perovskites have unblocked the efficiency of organic solar cells that for years was slowly increasing close to $12 \%$. Hybrid perovskites based solar cells are now reaching the efficiency levels of silicon solar cells and, due to the advantageous physical properties of the hybrid perovskites themselves, they represent a new class of solar cells. In this special issue, we present a series of original research articles dealing with some of the current research lines on hybrid perovskite devices, which cover the influence of the electron and hole transport layers, the importance of surface and interfaces, the stability improvement strategies to achieve long-term operation and the seek for lead-free materials.

The special issue starts with some articles of how the electron and hole transport layers affect the efficiency and the cost of hybrid perovskite devices. Chiang et al [2] study the use of IZO as a transparent conductive oxide for top illumination of perovskite solar cells to avoid the expensive (bottom) substrate that accounts by over $58 \%$ of the cost. Another article deals with alternatives $\mathrm{TiO}_{2}$, an electron transport material with low mobility because of bulk defects and that requires an expensive high-temperature processing. Zhou et al have thus considered $\mathrm{SnO} 2$ as a different option [3]. Then, Ono et al study the impact of pinhole defects at the hole transport layer on the device efficiency and stability, and study how to avoid the pinhole apparition during the spin coating process of Spiro-MeOTAD and polystyrene [4].

\footnotetext{
${ }^{1}$ Author to whom any correspondence should be addressed.
} 
Other aspects to be considered when optimizing the efficiency of the devices are the hybrid perovskite surfaces as well as the interfaces between the different layers in the device, since the transport properties are closely related to them. In this context, Liang et al study perovskite/fullerene heterojunctions and relate the anomalous hysteresis in the J-V curves due to the charge accumulation at the interface [5]. Jacques et al identify traces of an unknown structural feature in the fine-structure of x-ray diffraction Bragg spots, at an expanded region of the sample, probably near the sample surface [6]. Also, Zhumekenov et al study how to grow crystals of the electronic properties of $\mathrm{CH} 3 \mathrm{NH} 3 \mathrm{Pbl} 3$ exposing unconventional facets (i.e. the $\left(\begin{array}{lll}0 & 0 & 2\end{array}\right)$ ) instead of the usual $\left(\begin{array}{lll}2 & 0 & 0\end{array}\right)$ or $\left(\begin{array}{lll}1 & 1 & 2\end{array}\right)$ facets. They observe striking differences in the device performances depending on the facet [7].

Efficiency is not everything in a device. Long-term stability is necessary for commercialization, so it is necessary to control the stability of hybrid perovskites towards temperature, air, humidity or even UV exposure. This special issue presents different approaches to reach higher stability of these materials. One is the combination of 2D and 3D perovskites, as shown by Zhang et al when using BDAPbI4 and MAPbI3 [8]. Another possibility is to encapsulate the hybrid perovskites based solar cells to protect them from the air and the humidity, as it is reported by Emami et al using a scalable compatible process by laser-assisted encapsulation [9]. Another strategy consists in finding more robust perovskites. This approach is experimentally illustrated by Aygüler et al with inorganic metal halide perovskites $\mathrm{CsPbX} 3$ or KCF3SO3 [10]. Theoretically, inorganic perovskites have been studied by Huo et al [11] who have extensively explored by first-principles calculations the functionality as solar cell absorbers of almost 170 lead-free compounds, finally proposing some promising candidates as BaZrS3, BaHfSe3, SrZrSe3, SrHfSe3 and BaZrSe3.

All these works illustrate some of the main research trends in this rapidly evolving disci- pline. We hope that hybrid perovskites will be soon widespread in everybody's life, making a step forward in the renewable energy and optoelectronics fields.

\section{References}

[1] Kojima A, Teshima K, Shirai Y and Miyasaka T 2009 J. Am. Chem. Soc. 1316050

[2] Chiang Y-H, Peng C-C, Chen Y-H, Tung Y-L, Tsai S-Y and Chen P 2019 J. Phys. D: Appl. Phys. 51424002

[3] Zhou N, Cheng Q, Li L and Zhou H 2019 J. Phys. D: Appl. Phys. 51394001

[4] Ono L K, Hawash Z, Juarez-Perez E J, Qiu L, Jiang Y and Qi Y 2019 J. Phys. D: Appl. Phys. 51294001

[5] Liang P-W, Chen C-I, Chueh C-C and Jen A K Y 2019 J. Phys. D: Appl. Phys. 51504001

[6] Jacques V L R, Gallo-Frantz A, Tejeda A, Le Bolloc'h D, Lédée F, Trippé-Allard G, Garrot D, Fertey P, Deleporte E and Plantevin O 2019 J. Phys. D: Appl. Phys. 51314001

[7] Zhumekenov A A, Haque M A, Yin J, El-Zohry A M, Lee K J, Dursun I, Mohammed O F, Baran D and Bakr O M 2019 J. Phys. D: Appl. Phys. 51054001

[8] Zhang T, Hui Y, Chen L, Li G, Mao B and Zhao Y 2019 J. Phys. D: Appl. Phys. 51404001 [9] Emami S, Martins J, Madureira R, Hernandez D, Bernardo G, Mendes J and Mendes A 2019 J. Phys. D: Appl. Phys. 51074005

[10] Aygüler M F, Puscher B M D, Tong Y, Bein T, Urban A S, Costa R D and Docampo P 2019 J. Phys. D: Appl. Phys. 51334001

[11] Huo Z, Wei S-H and Yin W-J 2019 J. Phys. D: Appl. Phys. 51474003 